\title{
New insight in lymnaeid snails (Mollusca, Gastropoda) as intermediate hosts of Fasciola hepatica (Trematoda, Digenea) in Belgium and Luxembourg
}

\author{
Yannick Caron ${ }^{1 *}$, Koen Martens ${ }^{2}$, Laetitia Lempereur ${ }^{3}$, Claude Saegerman $^{4}$ and Bertrand Losson ${ }^{1}$
}

\begin{abstract}
Background: The present study aims to assess the epidemiological role of different lymnaeid snails as intermediate hosts of the liver fluke Fasciola hepatica in Belgium and Luxembourg.

Methods: During summer 2008, 7103 lymnaeid snails were collected from 125 ponds distributed in 5 clusters each including 25 ponds. Each cluster was located in a different biogeographic area of Belgium and Luxembourg. In addition, snails were also collected in sixteen other biotopes considered as temporary wet areas. These snails were identified as Galba truncatula $(n=2474)$ (the main intermediate host of F. hepatica in Europe) and Radix sp. ( $n=4629$ ). Moreover, several biological and non-biological variables were also recorded from the different biotopes. DNA was extracted from each snail collected using Chelex ${ }^{\otimes}$ technique. DNA samples were screened through a multiplex PCR that amplifies lymnaeid internal transcribed spacer 2 gene sequences (500-600 bp) (acting as an internal control) and a 124 bp fragment of repetitive DNA from Fasciola sp.

Results: Lymnaeid snails were found in 75 biotopes (53.2\%). Thirty individuals of G. truncatula (1.31\%) and 7 of Radix sp. (0.16\%) were found to be positive for Fasciola sp. The seven positive Radix sp. snails all belonged to the species R. balthica (Linnaeus, 1758). Classification and regression tree analysis were performed in order to better understand links and relative importance of the different recorded factors. One of the best explanatory variables for the presence/absence of the different snail species seems to be the geographic location, whereas for the infection status of the snails no obvious relationship was linked to the presence of cattle.
\end{abstract}

Conclusions: Epidemiological implications of these findings and particularly the role of $R$. balthica as an alternative intermediate host in Belgium and Luxembourg were discussed.

Keywords: Fasciola sp, Radix balthica, Galba truncatula, Multiplex PCR, Epidemiology

\section{Background}

Fasciola hepatica is a digenean platyhelminth parasite, also called liver fluke, which induces fasciolosis mainly in domestic ruminants and humans. This disease is responsible for important financial loss on livestock production worldwide. In northern Belgium (Flanders), the yearly cost of infection in dairy production was estimated to be

\footnotetext{
* Correspondence: ycaron@ulg.ac.be

'Research Unit in Parasitology and Parasitic Diseases, Department of Infectious and Parasitic Diseases, Faculty of Veterinary Medicine, University of Liège, B-4000 Liège, Belgium

Full list of author information is available at the end of the article
}

around 8.2 million euros [1], and approximately 52 million euros in Switzerland [2].

Liver fluke needs a lymnaeid snail as intermediate host to complete its life cycle. Although Galba truncatula plays this role in Europe [3,4], it seems that other lymnaeid species could also act as alternative intermediate hosts [5]. Globally about 20 species of Lymnaeidae were described as potential intermediate hosts of Fasciola spp. [4]. In Europe, several species were experimentally infected or found naturally infected with $F$. hepatica. These species belong to species of the genera Lymnaea [6-11]. Omphiscola [12-17], Stagnicola, Pseudosuccinea [18], and Radix 
$[6,8,11,16,17,19-22]$. These observations suggest that many different species of lymnaeid snails may be potential hosts for the larval stages of $F$. hepatica.

In a previous study, $R$. labiata (Rossmaessler, 1835) was suspected to act as an alternative intermediate host of $F$. hepatica in Belgium since it harbored the intramolluscan development and allowed subsequent shedding of cercariae. Furthermore, these metacercariae were as infective as those produced in G. truncatula as demonstrated by parasitological and serological data collected from experimentally infected rats [20]. Recently, a lymnaeid snail species collected in Ireland was found to be naturally infected by $F$. hepatica and was identified as $R$. peregra by PCR amplification and sequencing of internal transcribed spacer 2 (ITS-2) gene [22].

Systematics of the family Lymnaeidae is controversial as its members can exhibit a great diversity in shell morphology with extremely homogeneous internal anatomical traits [23]. Furthermore, for sibling species belonging to the genus Radix, morphometric analyses demonstrated, that shell shape was unsuitable to define homogeneously and discretely recognizable entities, because the variation was continuous [24]. Taxonomy, deduced from rDNA sequences, particularly the ITS-2 may help to differentiate between lymnaeid species [25].

Several techniques aim to detect Fasciola sp. in the snail intermediate host such as microscopy or molecular techniques [26]. The latter technique should be effective and cheap enough to screen large numbers of individuals for naturally infected snails. Some studies [22,27-32] used molecular biology - based tools to investigate prevalence of $F$. hepatica in lymnaeids, but very few were tested on naturally infected snails collected in the field.

The aims of the present study were firstly, to assess analytic reliability of DNA extraction and multiplex PCR during a nationwide sampling campaign. Secondly, the potential epidemiological role of other lymnaeid species (Radix spp.) was assessed regarding the presence of $F$. hepatica in Belgium and Luxembourg. Finally, the presence and abundance of snails and the prevalence of larval stages of $F$. hepatica in the snail populations were studied in relation with biological and non-biological variables pertaining to the studied ponds.

\section{Methods}

\section{Sampling}

Five biogeographic regions were characterized in Belgium and Luxembourg: Polders, Sand region, Loam region, Chalk region and Gutland (Figure 1). In each of these regions, five circular areas of $38 \mathrm{~km}^{2}$ were defined, into which 5 ponds were randomly selected. A total of 125 ponds were thus selected according to a strict a priori defined spatial design. Lymnaeid snails $(>4 \mathrm{~mm}$ ) were sampled in each pond (and surrounding permanent wet area) and additionally in 16 temporary wet areas during summer (July - August) 2008. Snails were collected during a maximum of 15 minutes in spots separated by $4-5$ meters all around each pond (irrespective to the presence/absence of snails) and immediately placed in a tube containing $70 \%$ alcohol. Several variables were also measured such as GPS coordinates, temperature, $\mathrm{pH}$, soil type (clay, silt, sand, stone), and presence of fence, cattle, trampling, and faecal

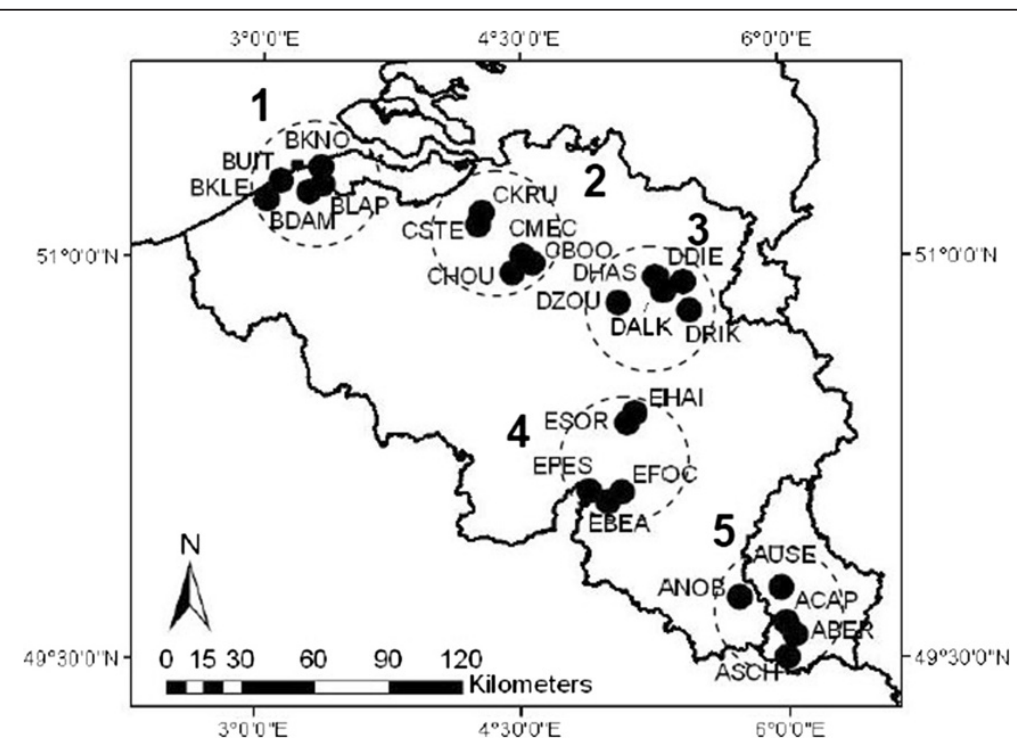

Figure 1 Location of the 25 pond clusters (abbreviations) spread over five biogeographic regions in Belgium/Luxembourg: 1) Polders (BKNO, BUIT, BKLE, BDAM, BLAP), 2) Sand region (CKRU, CSTE, CHOU, CBOO, CMEC), 3) Loam region (DHAS, DZOU, DALK, DRIK, DDIE), 4) Chalk region (ESOR, EPES, EBEA, EFOC, EHAI), 5) Gutland (ANOB, ASCH, ABER, ACAP, AUSE). 
pats. Ponds were classified in three types: (i) intensively used, mostly characterized by a surrounding environment with high agricultural or breeding of cattle activity, (ii) natural, representing ponds in nature reserves and (iii) extensively used, surrounded by environments with intermediate agricultural or cattle breeding activity. Morphological identification was based on a dichotomous key [33] allowing discrimination between G. truncatula and Radix sp. using a binocular microscope (x10). Snails were stored in alcohol $70 \%$ until further analyses.

\section{DNA extraction and pooling}

DNA extraction was based on Chelex ${ }^{\circ}$ method as previously described [34]. Briefly, the snail was mechanically disrupted with the help of a pellet mixer (Trefflab) in $100 \mu \mathrm{l}$ of Chelex ${ }^{\circ}$ 5\% (BioRad) and incubated for one hour at $56^{\circ} \mathrm{C}$ and $30 \mathrm{~min}$ at $95^{\circ} \mathrm{C}$ in a Peltier Thermal Cycler (MJ Research). The mixture was centrifuged at $13,000 \times \mathrm{g}$ for seven minutes. The supernatant was collected and stored at $-20^{\circ} \mathrm{C}$ until further analyses. DNA concentration and quality (260/280 wavelength ratio) were measured using a spectrophotometer (Thermo Scientific, NanoDrop 1000).

In order to reduce the number of PCRs, pools of individuals of the same genus were formed by mixing together one $\mu \mathrm{l}$ of each DNA sample with a maximum of 10 snails per pool. This mixture was considered undiluted. One $\mu \mathrm{l}$ of the mixture was then tested in the multiplex PCR described below.

The absence of internal control amplification (PCR inhibitors) for a pooled or an individual sample was assessed through $1 / 10$ and $1 / 100$ dilutions. Furthermore, the addition of $0.05 \%$ Bovine Serum Albumin (BSA) in the PCR mixture at 1/10 dilution was tested for samples with absence of internal control amplification whereupon negative samples were definitely excluded from the study.

\section{Multiplex PCR and sequencing reaction}

A multiplex PCR assay [34] was used to amplify a highly repeated 124 bp sequence (microsatellite) specific for Fasciola spp. [35] and ITS-2 rDNA sequence specific for lymnaeids (500-600 bp). ITS-2 sequence of the snail acts as a PCR internal control as its absence indicates potential presence of PCR inhibitors. The primers used for amplification of Fasciola spp. sequences were Fsh1 5'-GAT-CAA-TTC-ACC-CAT-TTC-CGT-TAG-TC C-TAC-3' and Fsh2 5'-AAA-CTG-GGC-TTA-AAC-G GC-GTC-CTA-CGG-GCA-3' and for lymnaeids ITS-2 amplification were News2 5'-TGT-GTC-GAT-GAA-GA A-CGC-AG-3' and Its2Rixo 5'-TTC-TAT-GCT-TAAATT-CAG-GGG-3' [36,37]. The sequences were amplified using a commercial kit (Taq PCR Master Mix, Qiagen) in a total volume of $25 \mu \mathrm{l}$ in a Peltier Thermal Cycler (M) Research) with an initial denaturation step at $95^{\circ} \mathrm{C}$ for five minutes, followed by 40 cycles, each comprising denaturation at $95^{\circ} \mathrm{C}$ for one minute, annealing at $56^{\circ} \mathrm{C}$ for one minute, extension at $72^{\circ} \mathrm{C}$ for one minute and a final extension step at $72^{\circ} \mathrm{C}$ for ten minutes. The amplification products were electrophoretically resolved in $2 \%$ agarose gels and stained with ethidium bromide. The limit of detection and specificity of this multiplex PCR were studied in a previous study [34].

ITS-2 rDNA sequence of 100 Radix sp. (93 randomly selected and 7 Fasciola sp. positive samples) were amplified and sequenced for species identification. ITS-2 DNA products were purified using MSB-Spin PCRapace (Invitek). Cycle sequencing reactions were performed (in duplicate and in both direction) by BigDye terminator v3.1 (3730 DNA analyzer; Applied Biosystems) by GIGA Genomics Facility (Liège University, Belgium). Consensus sequences were made according to the results of sequencing of the PCR products and were analyzed using BLASTn searches in GenBank (www.ncbi.nlm.nih.gov) and aligned using BioEdit 7.0.9.0 [38].

\section{Statistical analysis \\ Classification and regression tree (CART) analysis}

A CART analysis is a non-linear and non-parametric model that is fitted by binary recursive partitioning of multidimensional covariate space [39]. Using CART 6.0 software (Salford Systems, San Diego, CA, USA), the analysis successively splits the dataset into increasingly homogeneous subsets until it is stratified and meets specified criteria. CART performs cross validation by growing maximal trees on subsets of data then calculating error rates based on unused portions of the data set.

When the primary splitting variable is missing for an individual observation, that observation is not discarded but, instead, a surrogate splitting variable is sought. Thus, the program uses the best available information in the face of missing values. In datasets of reasonable quality, this allows all observations to be used. This is a significant advantage of this methodology over more traditional multivariate regression modelling, in which observations that are missing any of the predictor variables are often discarded. Further details about CART are presented in previously original papers or reviews $[40,41]$.

A CART analysis was conducted on two data sets. Four different analyses were performed. For CART I and II, the dependant variable was the presence of Radix sp. or G. truncatula, respectively and the independent variables were the county of origin of the pond, geologic characteristics of the soil, type and depth of pond, and temperature and $\mathrm{pH}$ of the water. For CART III and IV, the dependant variable was the presence of infected Radix sp. or G. truncatula in ponds, respectively and the independent variables were the presence of fences, (traces of) presence of 
animals, the type of pond and the number of specimens of Radix sp. or G. truncatula.

\section{Assessment of lymnaeid presence data}

The presence of Radix sp. and G. truncatula in all the biotopes were compared in order to assess their agreement with our results using Fisher's exact test [42] and concordance analysis. The level of agreement was also expressed in terms of indices of positive and negative agreement [43], respectively the observed agreement proportion for positive and negative results (i.e., presence and absence).

\section{Results}

\section{Sample collection}

Seven thousand one hundred and three lymnaeid snails were collected during summer 2008 of which 2474 were morphologically identified as G. truncatula (34.8\%) and 4629 as Radix sp. (65.2\%) (Figure 2). Lymnaeid snails were found in $53.2 \%(75 / 141)$ of biotopes investigated, in which G. truncatula was found in $60 \%(45 / 75)$ of all the biotopes and $80 \%(36 / 45)$ in ponds, whereas Radix sp. was recorded in $64 \%(48 / 75)$ of all the biotopes and $85.4 \%(41 / 48)$ in ponds. A percent of $35.8 \%(886 / 2474)$ and $8.2 \%(378 / 4629)$ of the collected G. truncatula and Radix sp. were collected from the sixteen temporary wet areas respectively. G. truncatula and Radix sp. were present together in 24\% (18/75) of the biotopes. G. truncatula was most abundant in Sand, Loam and Chalk Regions (83.2\%). Most of the Radix species were found in Polders (57.2\%), where G. truncatula were relatively under-represented.

\section{Multiplex PCR and sequencing}

Two thousand four hundred and seventy four G. truncatula were pooled in 271 batches. Although different dilution factors were tested (undiluted, 1/10, 1/100 and 1/10+ BSA), 195 snails $(7.89 \%)$ were eliminated from the study due to PCR inhibition. Twenty eight pools containing 270

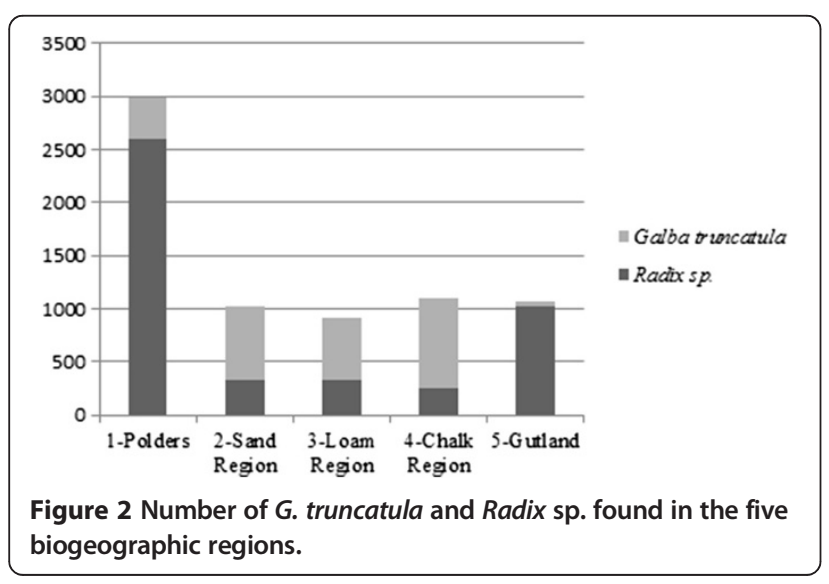

snails were found positive for Fasciola sp. These 270 snails were individually screened using the multiplex PCR and 30 G. truncatula were found positive, resulting in a prevalence of $1.31 \%(30 / 2279)$.

Four thousand six hundred and twenty nine Radix sp. were pooled in 486 batches of a maximum of 10 snails each. Four hundred and four snails (8.77\%) were eliminated from the study due to PCR inhibition. The $124 \mathrm{bp}$ specific band of Fasciola sp was amplified in six pools (60 snails). These 60 snails were individually tested and 7 snails were positive. The frequency of snails with parasite DNA in Radix sp. was estimated to be $0.16 \%$ (7/4225). The geographical location of ponds where Fasciola sp. infected snails was found is illustrated in Figure 3.

In order to accurately identify Radix sp., ITS-2 of the 7 Fasciola sp. DNA positive Radix sp. and 93 other Radix sp. randomly selected were sequenced. Ninety eight sequences (named as PRT1) [GenBank: KC544264] were found to be $100 \%$ identical to $R$. peregra (Müller, 1774) (GenBank: HQ283271.1). The two remaining sequences (named as PRT2) [GenBank: KC544265] were identified as 100\% identical to R. labiata (Rossmaessler, 1835) [GenBank AJ319637.1]. The 7 Radix sp. positive for Fasciola sp. all belonged to PRT1.

\section{Statistical analysis \\ CART analysis}

Presence/absence The presence/absence of G. truncatula (CART I) and Radix sp. (CART II) were assessed for the 125 sampled ponds using CART analysis. Table 1 presents results of both CART analyses. The geographic location seems to be the best explanatory variable for the presence of G. truncatula and Radix sp. Presence of G. truncatula seems strongly linked to $\mathrm{pH}$, water temperature and ground type whereas presence of Radix sp. is essentially related to the ground type.

Infected/non infected The infection status of G. truncatula (CART III) and Radix sp. (CART IV) was also assessed using CART analysis. Table 2 presents results of both CART analyses. The number of collected snails was identified as the best explanatory factor. Factors relative to cattle presence (trampling, faecal pats, and fence) was not linked to the infection status.

\section{Assessment of lymnaeid presence data}

The distribution of G. truncatula and Radix sp. was not significantly different within biotopes (Fischer's exact test; $P=0.34$ ). The $P_{\text {pos }}$ and $P_{\text {neg }}$ are 0.39 and 0.70 , respectively.

\section{Discussion}

This is the first time a molecular based technique has been used to assess natural Fasciola sp. prevalence in 


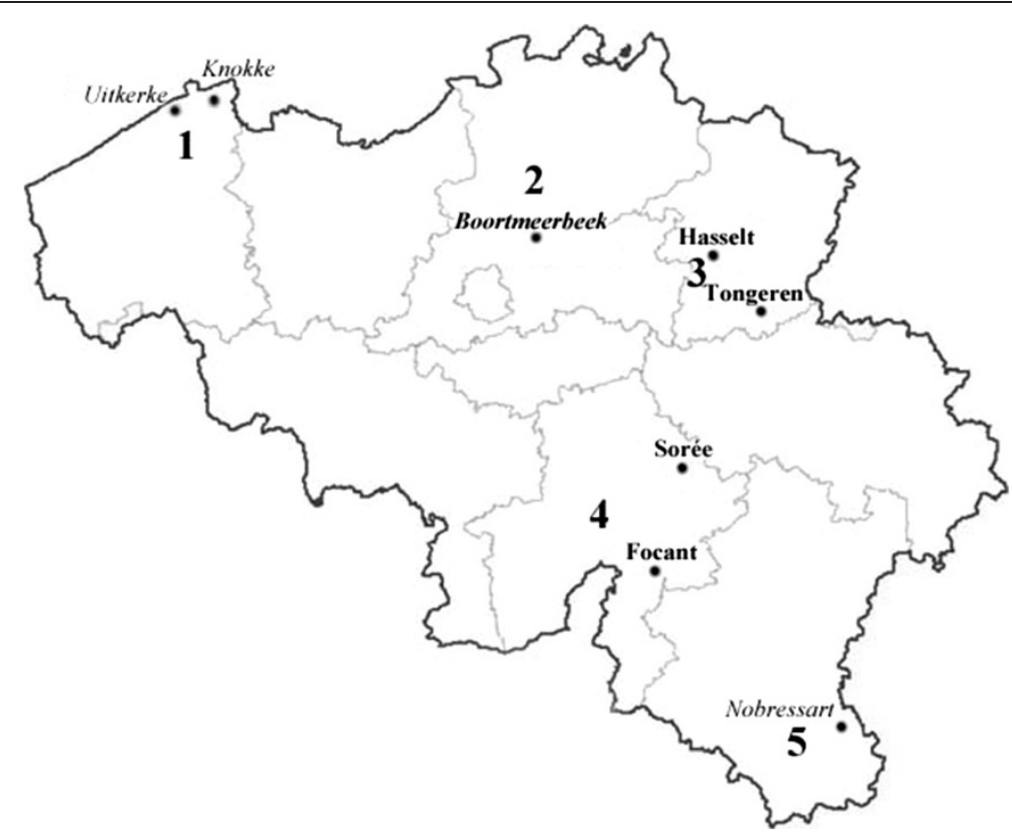

Figure 3 Location of the ponds where Fasciola sp. infected snails species were found: 1) Polders, 2) Sand region, 3) Loam region, 4) Chalk region, 5) Gutland; Bold for G. truncatula; Italic for Radix sp.; Italic and bold for pond where G. truncatula and Radix sp. were found infected.

intermediate hosts in Belgium. One hundred and twenty five ponds and sixteen other interesting areas in five different biogeographic regions in Belgium and Luxembourg were sampled for snails with environmental factors information. In Belgium in 2008, winter and spring were particularly mild. Furthermore, during that summer the rainfall and the number of rainy days were quite abnormal (Royal Meteorological Institute of Belgium; http://www. meteo.be). Those conditions are the most suitable for snail development. More than half of these biotopes (53.2\%) were colonized with lymnaeid snails. Soil composition in Flanders (sand, silt) in Polders, Sand Region, and Loam region seem to be suitable for the development of lymnaeid snails. A great diversity in shell morphology with extremely homogenous anatomical traits created a great confusion regarding the systematics of lymnaeids especially

Table 1 CART analysis I (G. truncatula) and II (R. balthica): presence/absence; explanatory percentage for each of the independent variables was indicated

\begin{tabular}{lclc}
\hline G. truncatula & \multicolumn{3}{c}{ R. balthica } \\
\hline County & $100 \%$ & County & $100 \%$ \\
$\mathrm{pH}$ & $73 \%$ & Ground type & $59.25 \%$ \\
Water temperature & $46.81 \%$ & Pond type & $23.04 \%$ \\
Ground type & $45.32 \%$ & Water temperature & $23.04 \%$ \\
Pond type & $13.85 \%$ & $\mathrm{pH}$ & $14.25 \%$ \\
Tree sensibility & $84.44 \%$ & Tree sensibility & $81.25 \%$ \\
Tree sensitivity & $81.25 \%$ & Tree sensitivity & $60.22 \%$ \\
\hline
\end{tabular}

those belonging to the genus Radix. Some authors [25] considered $R$. peregra (Müller, 1774) as a synomym of $R$. ovata (Draparnaud, 1805) and R. balthica (Linnaeus, 1758), while others maintained all species as valid [44]. In this present study, $R$. balthica was used to represent all of these synonymous species (R. peregra $=R$. ovata $=R$. balthica $=$ PRT1) because the name $R$. peregra was abandoned by Bargues et al. [37]. The genus Radix was more represented than the main intermediate host of $F$. hepatica since only one third of the 7103 collected snails belonged to the species G. truncatula. Indeed, $R$. balthica (= R. peregra $=R$. ovata) is considered as a very widespread and resilient species [45], which is able to live in waste water [46], in contrast to G. truncatula. Furthermore, ponds are not typical biotopes of G. truncatula, which prefers peripheral extremities of open drainage furrows, spring head surroundings, temporary wet meadow, and ditches [47]. In sixteen of those specific biotopes, G. truncatula (35.8\%) was more frequent than Radix sp. (8.2\%). However, the

Table 2 CART analysis II (G. truncatula) and IV (R. balthica): infection status; explanatory percentage for each of the independent variables was indicated

\begin{tabular}{lclc}
\hline G. truncatula & \multicolumn{3}{c}{ R. peregra } \\
\hline Number of snail & $100 \%$ & Number of snail & $100 \%$ \\
Pond type & $22.14 \%$ & Ground type & $29.84 \%$ \\
Tree sensibility & $83.33 \%$ & Tree sensibility & $100 \%$ \\
Tree sensitivity & $97.78 \%$ & Tree sensitivity & $82.35 \%$ \\
\hline
\end{tabular}


Fisher's exact test indicates that there is no difference between lymnaeid fauna composition and biotopes (permanent wet vs temporary wet areas). Prevalence of $F$. hepatica in permanent and temporary water habitats were never compared even though some consider these as equal [48].

Establishment of pools including a maximum of 10 snails was advantageous to reduce PCR number and consequently cost and time consumption. The proportion of PCR inhibition was relatively high despite dilution and use of BSA [27,34]. More than 66\% (130/195) of the discarded G. truncatula snails were collected in a tractor track probably polluted with some PCR inhibitors (complex polysaccharide, humic acid, or proteinase).

Fasciola sp. prevalence was evaluated to $1.31 \%$ in G. truncatula and $0.16 \%$ in Radix sp using an optimized multiplex PCR. This PCR-based prevalence is relatively low in the main intermediate host of liver fluke in Europe, particularly when compared to prevalence obtained with microscopy-based techniques [26]. This could be due to the pooling process, which is responsible for a dilution of PCR available DNA (up to 1/100). However, in a previous study [34] a pool containing the DNA from one F. hepatica naturally infected snail and 9 negative specimens, was found positive using the same technique (total DNA concentration of $100 \mathrm{pg}$ (1/10.000 dilution)). Only two studies assessed the prevalence of Fasciola sp. in naturally infested G. truncatula with PCR-based techniques. In Poland, a preliminary study using a limited number of snails $(<200)$ and based on the same $124 \mathrm{bp}$ repeated sequence [29] estimated the prevalence to be $26.2 \%$. In Switzerland [32] more than 4700 snails were collected with a prevalence estimated to be $7 \%$ using a real time TaqMan PCR. Nevertheless, these snails were collected in infected cattle farms and the real regional prevalence was probably overestimated.

Fasciola sp. infection rates in other intermediate hosts vary greatly from less than $1 \%$ to more than $60 \%$ : $0.032 \%$ (1/3072) in L. modicella [31]; 1.5\% (79/5246) in Fossaria cubensis [28]; 51.3\% (123/240) in L. columella and 61.8\% (21/34) in L. viatrix [27]. In Ireland, a study [22] using PCR amplifying a part of the cytochrome c oxidase subunit 1 (cox 1) gene provided prevalence of $73.9 \%(n=17)$ in Succinea sp. and from $10.3 \%(\mathrm{n}=8)$ to $61.1 \%(\mathrm{n}=22)$ in $R$. balthica $(=R$. peregra $=R$. ovata $)$. Radix balthica may harbour incidental infection and experimental infections are difficult to implement $[49,50]$. However, other authors have shown $[20-22,25]$ that $R$. balthica can maintain intermolluscan stages of $F$. hepatica enabling the parasite to multiply. The frequency of snails with parasite DNA obtained for $R$. balthica in this study was very low and its epidemiological role seems weak. Nevertheless, $R$. balthica $(=R$. peregra $=R$. ovata $)$ are more aquatic and more invasive [51] than amphibious G. truncatula and could lead to the extension of fasciolosis in previously free areas, particularly where G. truncatula is absent [6,13,22]. The genus Radix seems to be very permissive to Trematoda infection as natural infections were recorded for F. gigantica [52] Fascioloides magna [51], Trichobilharzia regenti [53,54], and T. franki [55], and finally echinotostomatid species [37]. The reasons for this parasitic tolerance are poorly understood although widespread distribution, high density and immune mechanisms of this genus seem to be the most plausible hypothesis. Studies on niche modeling predicted northward expansion of $R$. balthica $(=R$. peregra $=R$. ovata), as already observed in Sweden probably due to increasing water temperature in lakes (M. Pfenninger, unpublished data). During a previous study [20], $R$. labiata (Rossmaessler, 1835) (= PRT2) was shown to be able to shed cercariae. The metacercariae obtained were infective to rats in the laboratory contrary to metacercariae obtained from experimentally infected $R$. balthica. This could be linked to the difficulties encountered during breeding of this last species under laboratory conditions (highest average mortality: 54\%) [20] or prevalence variability between populations as it was described for G. truncatula [56]. Furthermore this species was under-represented in the samples.

The presence/absence of lymnaeids and their infestation status were both assessed using CART analysis. Galba truncatula seems to be more stenoecious, since this species is very sensitive to environmental factors ( $\mathrm{pH}$ and water temperature for example) and lives in a more restricted range of habitats [47] than $R$. balthica (the "travelling species") which is more tolerant to variable environmental conditions.

The number of snails collected was found as the best explanatory factor related to the infection status. Surprisingly, presence of cattle (trampling, stools, fences) was not found to be a factor linked to the snail infestation status. However, a lack of power in the analyses is possible, because of the low prevalence of infection observed and this might have caused non-significant correlations. This could also suggest that wild fauna can intervene in the maintenance of $F$. hepatica life cycle. Generally, farmers consider that the presence of ponds in their meadow has a negative impact on cattle breeding, while European funds support the maintenance and digging of ponds in order to promote biodiversity. This last result could highlight the importance of temporary aquatic biotopes in the epidemiology of $F$. hepatica in Belgium. Nevertheless, pond types (intensive, natural and extensive) were not very informative on the infestation status (less than 30\% in Cart analysis Table 2).

Digenetic trematode species are usually oioxenous (one parasite species infect a single snail species) or stenoxenous (one parasite species infect several closely related snail species). But the case of $F$. hepatica seems to 
be different as it shows a broad capacity to infect local and phylogenetically distant lymnaeid species [44]. Therefore, rather than focusing on a single, or a handful of snail species, fasciolosis control programs should cover a broader spectrum of intermediate hosts that inhabit diverse habitats and ecological conditions [44]. The multiplex PCR method used in this study confirms this approach can address such concerns and highlights the role of $R$. balthica $(=R$. peregra $=R$. ovata $)$ in the epidemiology of $F$. hepatica in Belgium.

\section{Conclusion}

A multiplex PCR was used to assess the parasitological status of 7103 lymnaeid snails collected in natural biotopes in Belgium. This technique was fully reliable and this is the first time in Belgium that naturally infected snails collected in the field were analyzed through molecular biology - based tools.

\section{Competing interests}

The authors declare that they have no competing interests.

\section{Authors' contributions}

YC wrote the manuscript and made sampling and analysis. KM managed the PONDSCAPE project and participated in the reviewing process. LL participated in the reviewing process. CS made statistical analysis. BL supervised the whole process. All authors read and approved the final version of the manuscript.

\section{Acknowledgment}

This study had been made in the frame of the PONDSCAPE project ("Towards a sustainable management of pond diversity at the landscape level" - http://www.pondscape.be), financed by the European Union and the Belgian Science Policy (SD/BD/02A). The authors would like to thank PONDSCAPE partners and the Interdisciplinary Group of Applied Genoproteomics (GIGA) Genomic Facility (http://www.giga.ulg.ac.be) for sequencing support.

\section{Author details}

${ }^{1}$ Research Unit in Parasitology and Parasitic Diseases, Department of Infectious and Parasitic Diseases, Faculty of Veterinary Medicine, University of Liège, B-4000 Liège, Belgium. ${ }^{2}$ Freshwater Biology, Royal Belgium Institute of Natural Sciences, Brussels, Belgium. ${ }^{3}$ Institute of Infection, Immunity \& Inflammation, College of Medical, Veterinary \& Life Sciences, University of Glasgow, Bearsden Road, Glasgow G61 1QH Scotland, UK. ${ }^{4}$ Research Unit in Epidemiology and Risk Analysis applied to Veterinary Sciences (UREAR-ULg), Department of Infectious and Parasitic Diseases, Faculty of Veterinary Medicine, University of Liège, B-4000 Liège, Belgium.

Received: 16 October 2013 Accepted: 10 February 2014 Published: 13 February 2014

\section{References}

1. Charlier J, De Cat A, Forbes A, Vercruysse J: Measurement of antibodies to gastrointestinal nematodes and liver fluke in meat juice of beef cattle and associations with carcass parameters. Vet Parasitol 2009, 166(3-4):235-240.

2. Schweizer G, Braun U, Deplazes P, Torgerson PR: Estimating the financial losses due to bovine fasciolosis in Switzerland. Vet Rec 2005, 157(7):188-193.

3. Taylor EL: Fascioliasis and the Liver Fluke, Volume 64. Rome: FAO Agricultural Studies; 1965.

4. Torgerson P, Claxton J: Epidemiology and control. In Fasciolosis. Edited by Dalton JP. Wallingford, Oxon, U.K: CABI Publishing; 1999:113-149.

5. Boray JC: The potential impact of exotic Lymnaea spp. on fascioliasis in Australasia. Vet Parasitol 1978, 4:127-141.
6. Boray JC: Studies on the relative susceptibility of some lymnaeids to infection with Fasciola hepatica and F. gigantica and on the adaptation of Fasciola spp. Ann Trop Med Parasitol 1966, 60(1):114-124.

7. Dreyfuss $G$, Abrous M, Rondelaud D: The susceptibility of Lymnaea fuscus to experimental infection with Fasciola hepatica. J Parasitol 2000, 86(1):158-160.

8. Dreyfuss $G$, Vignoles P, Abrous M, Rondelaud D: Unusual snail species involved in the transmission of Fasciola hepatica in watercress beds in central France. Parasite 2002, 9(2):113-120.

9. Furmaga $S$, Gundlach JL: Lymnaea stagnalis L. as one more intermediate host of Fasciola hepatica. Acta Parasitol 1967, 15(32):231-235.

10. Furmaga S, Gundlach JL: Lymnaea stagnalis as a source of infection with Fasciola hepatica. Acta Parasitol 1967, 15(32):237-241.

11. Furmaga S, Gundlach JL: Studies on the participation of some snail species of the family Lymnaeidae in the life cycle of Fasciola hepatica. Acta Parasitol 1969, 17(13):115-118.

12. Abrous M, Rondelaud D, Dreyfuss G: Paramphistomum daubneyi and Fasciola hepatica: the effect of dual infection on prevalence and cercarial shedding in preadult Lymnaea glabra. J Parasitol 1996, 82(6):1026-1029.

13. Abrous M, Rondelaud D, Dreyfuss $G$, Cabaret J: Unusual transmission of the liver fluke, Fasciola hepatica, by Lymnaea glabra or Planorbis leucostoma in France. J Parasitol 1998, 84(6):1257-1259.

14. Abrous M, Rondelaud D, Dreyfuss G, Cabaret J: Infection of Lymnaea truncatula and Lymnaea glabra by Fasciola hepatica and Paramphistomum daubneyi in farms of central France. Vet Res 1999, 30(1):113-118.

15. Dreyfuss G, Novobilsky A, Vignoles P, Bellet V, Koudela B, Rondelaud D: Prevalence and intensity of infections in the lymnaeid snail Omphiscola glabra experimentally infected with Fasciola hepatica, Fascioloides magna and Paramphistomum daubneyi. J Helminthol 2007, 81(1):7-12.

16. Sindou P, Cabaret J, Rondelaud D: Survival of snails and characteristic lesions of Fasciola hepatica infection in four European species of Lymnaea. Vet Parasitol 1991, 40(1-2):47-58.

17. Vignoles P, Dreyfuss $G$, Rondelaud D: Redial growth and cercarial productivity of Fasciola hepatica in three species of young lymnaeid snails. J Helminthol 2002, 76(3):269-272.

18. Pointier JP, Coustau C, Rondelaud D, Theron A: Pseudosuccinea columella (Say 1817) (Gastropoda, Lymnaeidae), snail host of Fasciola hepatica: first record for France in the wild. Parasitol Res 2007, 101:1389-1392.

19. Boray JC: Host-parasite relationship between Lymnaeid snails and Fasciola hepatica. In Proceedings of the Third International Conference of the World Association for the Advancement of Veterinary Parasitology. Edited by Soulsby EJL. Lyon, France: School of Veterinary Medicine; 1967:132-140.

20. Caron Y, Lasri S, Losson B: Fasciola hepatica: an assessment on the vectorial capacity of Radix labiata and R. balthica commonly found in Belgium. Vet Parasitol 2007, 149(1-2):95-103.

21. Dreyfuss $G$, Vignoles P, Rondelaud D: Variability of Fasciola hepatica infection in Lymnaea ovata in relation to snail population and snail age. Parasitol Res 2000, 86(1):69-73.

22. Relf V, Good B, McCarthy E, de Waal T: Evidence of Fasciola hepatica infection in Radix peregra and a mollusc of the family Succineidae in Ireland. Vet Parasitol 2009, 163(1-2):152-155.

23. Correa AC, Escobar JS, Noya O, Velasquez LE, Gonzalez-Ramirez C, HurtrezBousses S, Pointier JP: Morphological and molecular characterization of Neotropic Lymnaeidae (Gastropoda: Lymnaeoidea), vectors of fasciolosis. Infect Genet Evol 2011, 11(8):1978-1988.

24. Pfenninger M, Cordellier M, Streit B: Comparing the efficacy of morphologic and DNA-based taxonomy in the freshwater gastropod genus Radix (Basommatophora, Pulmonata). BMC Evol Biol 2006, 23:100.

25. Bargues MD, Mas-Coma S: Reviewing lymnaeid vectors of fascioliasis by ribosomal DNA sequence analyses. J Helminthol 2005, 79(3):257-267.

26. Caron Y, Rondelaud D, Losson B: The detection and quantification of a digenean infection in the snail host with special emphasis on Fasciola sp. Parasitol Res 2008, 103(4):735-744.

27. Cucher MA, Carnevale S, Prepelitchi L, Labbe JH, Wisnivesky-Colli C: PCR diagnosis of Fasciola hepatica in field-collected Lymnaea columella and Lymnaea viatrix snails. Vet Parasitol 2006, 137(1-2):74-82.

28. Kaplan RM, Dame JB, Reddy GR, Courtney CH: The prevalence of Fasciola hepatica in its snail intermediate host determined by DNA probe assay. Int J Parasitol 1997, 27(12):1585-1593. 
29. Kozak M, Wedrychowicz H: The performance of a PCR assay for field studies on the prevalence of Fasciola hepatica infection in Galba truncatula intermediate host snails. Vet Parasitol 2010, 168(1-2):25-30.

30. Martinez-Ibeas AM, Gonzalez-Warleta M, Martinez-Valladares M, CastroHermida JA, Gonzalez-Lanza C, Minambres B, Ferreras C, Mezo M, MangaGonzalez MY: Development and validation of a mtDNA multiplex PCR for identification and discrimination of Calicophoron daubneyi and Fasciola hepatica in the Galba truncatula snail. Vet Parasitol 2013, 195(1-2):57-64.

31. Rognlie MC, Dimke KL, Potts RS, Knapp SE: Seasonal transmission of Fasciola hepatica in Montana, USA, with detection of infected intermediate hosts using a DNA-based assay. Vet Parasitol 1996, 65(3-4):297-305.

32. Schweizer G, Meli ML, Torgerson PR, Lutz H, Deplazes P, Braun U: Prevalence of Fasciola hepatica in the intermediate host Lymnaea truncatula detected by real time TaqMan PCR in populations from 70 Swiss farms with cattle husbandry. Vet Parasitol 2007, 150(1-2):164-169.

33. Janssen AW, Vogel EF: Zoetwatermollusken van Nederland. Amsterdam: Nederlandse Jeugdbond voor Natuurstudie; 1965.

34. Caron Y, Righi S, Lempereur L, Saegerman C, Losson B: An optimized DNA extraction and multiplex PCR for the detection of Fasciola sp. in lymnaeid snails. Vet Parasitol 2011, 178(1-2):93-99.

35. Kaplan RM, Dame JB, Reddy GR, Courtney $\mathrm{CH}$ : A repetitive DNA probe for the sensitive detection of Fasciola hepatica infected snails. Int J Parasitol 1995, 25(5):601-610.

36. Almeyda-Artigas RJ, Bargues MD, Mas-Coma S: ITS-2 rDNA sequencing of Gnathostoma species (Nematoda) and elucidation of the species causing human gnathostomiasis in the Americas. J Parasitol 2000, 86(3):537-544.

37. Bargues MD, Vigo M, Horak P, Dvorak J, Patzner RA, Pointier JP, Jackiewicz M, Meier-Brook C, Mas-Coma S: European Lymnaeidae (Mollusca: Gastropoda), intermediate hosts of trematodiases, based on nuclear ribosomal DNA ITS-2 sequences. Infect Genet Evol 2001, 1(2):85-107.

38. Hall TA: BioEdit: a user-friendly biological sequence alignment editor and analysis program for Windows 95/98/NT. Nucl Acids Symp Ser 1999, 41:95-98.

39. Breiman L, Friedman JH, Olshen RA, Stone CJ: Classification and Regression Trees. California, USA: Pacific Grove; 1984

40. Zanella G, Martinelle L, Guyot H, Mauroy A, De Clercq K, Saegerman C: Clinical pattern characterization of cattle naturally infected by BTV-8. Transbound Emerg Dis 2013, 60(3):231-237.

41. Saegerman C, Porter SR, Humblet MF: The use of modelling to evaluate and adapt strategies for animal disease control. Rev Sci Tech 2011, 30(2):555-569.

42. Dagnelie P: Statistique Théorique Et Appliquée. Inférence Statistique À Une Et À Deux Dimensions, vol. Tome 2. Bruxelles, Belgique: De Boek Université; 1998.

43. Cicchetti DV, Feinstein AR: High agreement but low kappa: II. Resolving the paradoxes. J Clin Epidemiol 1990, 43(6):551-558.

44. Correa AC, Escobar JS, Durand P, Renaud F, David P, Jarne P, Pointier JP, Hurtrez-Bousses S: Bridging gaps in the molecular phylogeny of the Lymnaeidae (Gastropoda: Pulmonata), vectors of fascioliasis. BMC Evol Biol 2010, 10:381.

45. Pfenninger $M$, Salinger $M$, Haun $T$, Feldmeyer B: Factors and processes shaping the population structure and distribution of genetic variation across the species range of the freshwater snail Radix balthica (Pulmonata, Basommatophora). BMC Evol Biol 2011, 11:135.

46. Baur B, Ringeis $B$ : Changes in gastropod assemblages in freshwater habitats in the vicinity of Basel (Switzerland) over 87 years. Hydrobiologia 2002, 479:1-10.

47. Rondelaud D, Vignoles P, Dreyfuss G: La Limnée Tronquée, Un Mollusque D'intgérêt Médical Et Vétérinaire. Limoges: Presses Universitaires de Limoges; 2009.

48. Chapuis E, Trouve S, Facon B, Degen L, Goudet J: High quantitative and no molecular differentiation of a freshwater snail (Galba truncatula) between temporary and permanent water habitats. Mol Ecol 2007 16(16):3484-3496.

49. MCReath AM: Aspects of host defense mechanism of Lymnaea peregra and Lymnaea palustris against sporocysts of Fasciola hepatica. Parasitology 1978, 77:R15-R115.

50. Smith G, Crombie JA: The rate of attachment of Fasciola hepatica miracidia to various species of lymnaeid. J Parasitol 1982, 68(5):965-966.

51. Faltynkova A, Horackova E, Hirtova L, Novobilsky A, Modry D, Scholz T: Is Radix peregra a new intermediate host of Fascioloides magna
(Trematoda) in Europe ? Field and experimental evidence. Acta Parasitol 2006, 51:87-90.

52. Velusamy R, Singh BP, Raina OK: Detection of Fasciola gigantica infection in snails by polymerase chain reaction. Vet Parasitol 2004, 120(1-2):85-90.

53. Hunova K, Kasny M, Hampl V, Leontovyc R, Kubena A, Mikes L, Horak P: Radix spp.: Identification of trematode intermediate hosts in the Czech Republic. Acta Parasitol 2012, 57(3):273-284.

54. Skirnisson $K$, Aldhoun JA, Kolarova L: A review on swimmer's itch and the occurrence of bird schistosomes in Iceland. J Helminthol 2009, 83(2):165-171.

55. Jouet D, Skirnisson K, Kolarova L, Ferte H: Molecular diversity of Trichobilharzia franki in two intermediate hosts (Radix auricularia and Radix peregra): a complex of species. Infect Genet Evol 2010, 10(8):1218-1227.

56. Dreyfuss G, Vignoles P, Mekroud A, Rondelaud D: The presence of uninfected Omphiscola glabra in a breeding of infected Galba truncatula enhanced the characteristics of snail infections with Fasciola hepatica. Parasitol Res 2006, 99(2):197-199.

doi:10.1186/1756-3305-7-66

Cite this article as: Caron et al:: New insight in lymnaeid snails

(Mollusca, Gastropoda) as intermediate hosts of Fasciola hepatica

(Trematoda, Digenea) in Belgium and Luxembourg. Parasites \& Vectors 2014 7:66.

\section{Submit your next manuscript to BioMed Central and take full advantage of:}

- Convenient online submission

- Thorough peer review

- No space constraints or color figure charges

- Immediate publication on acceptance

- Inclusion in PubMed, CAS, Scopus and Google Scholar

- Research which is freely available for redistribution

Submit your manuscript at www.biomedcentral.com/submit
C) Biomed Central 